\begin{tabular}{cc}
\hline EEJ 11 (1) (2021) 1-16 \\
UNNES \\
English Education Journal \\
http://journal.unnes.ac.id/sju/index.php/eej
\end{tabular}

\title{
The Realization of Lecturers' Code-Switching in English Teaching and Learning Process At Dian Nuswantoro Univesity
}

\author{
Dyah Ayu Enggaring Tyas ${ }^{1 凶}$, Dwi Rukmini $^{2}$, Abdurrachman Faridi ${ }^{2}$ \\ 1. SDN Gendongan 01 Salatiga, Indonesia \\ 2. Universitas Negeri Semarang, Indonesia
}

\begin{tabular}{l}
\hline Article Info \\
\hline Article History: \\
Accepted 20 \\
September 2020 \\
Approved 11 \\
November 2020 \\
Published 15 March \\
2021 \\
\hline
\end{tabular}

Keywords: English teaching and learning process, types of code-switching, functions of codeswitching

\begin{abstract}
This study focuses on the analysis of code-switching occurred in the English teaching and learning process at non-English department class. This study examines the forms and functions of code-switching in the classroom at the lecturing process of English major as conduced at non-English department of Dian Nuswantoro university. Findings of the study showed that (1) the teaching learning process of non-English department class at Dian Nuswantoro university students employed various kinds of code-switching both by lecturers and the students with the dominant used was inter-sentential codeswitching/full sentence code-switching. (2) there were various functions of code-switching utilized by the lecturer and students in the lecturing process, such as put an interjection in the middle of speech, to give emphasis toward certain topic, to repeat the speech, to give more description about certain topic, to talk about particular topic, to soften and straighten the request or command, to exclude others from the discussion, to express group identity, and to quote somebody's utterances. Further studies hopefully can explore deeply about code-switching where lecturers teach English department students and uncover the lecturer and students' perception on the occurrence of code-switching as the comparison to this current study.
\end{abstract}

\footnotetext{
$\triangle$ Correspondence Address:

J1. Margorejo No.5, Gendongan, Kec. Tingkir, Kota Salatiga, Jawa Tengah 50743, Indonesia

E-mail: dyah.ayu.enggaring@gmail.com
} 


\section{INTRODUCTION}

In the field of education, English has been introduced and learned by students to improve the quality of human resources. One of the objectives of the foreign language teaching and learning is to facilitate students' acquisition and communication in the target language. In achieving this objective, English teacher/lecturer should facilitate students with English as a medium of instruction during classroom interaction, since the use of the language can develop students' own in-built language scheme (Margana, 2008). Furthermore, Wilson (2004) states that a language acquirer who is at "level 1 " must receive comprehensive input that is at "level i+1" (p. 3). It implies that in teaching English must be provided along with comprehensive input in the target language which will result in the students' acceleration in acquiring English language proficiency. As stated by Krashen and Terrel in Payne (2011) English teachers are stimulated to create communicative situations in English without resource to mother language, because the application of mother language inclusion would only obstruct the process of English language teaching and learning. Furthermore, a good input from language teacher who only uses target language would result in a good learning outcome too.

However, in reality, teachers often have difficulties in delivering English as a foreign language in the classroom interaction. Moreover, teachers are required to be able to communicate their ideas and views to the students which are easily understood by them as well. Both teacher and students are basically not native speaker which might add up some constraints in the teaching and learning process. Furthermore, some strategies are employed either related to the use of the choice of language learning strategies or the way in delivering the materials. As an example, if the students find it difficult to understand what the teachers explain, they commonly switch the language to their native language that is easily understood by the students. Hence, it is inevitable for teachers and students to be engaged in various cases involving the use of mother language.

One of the strategies used by the language teacher is code-switching applied in teaching and learning process which the teacher and students may consciously or unconsciously be aware of the use of it. The strategies of switching code by the teachers in English instruction is a lingual phenomenon associating with the communication goals. Code switching however, is still debatable issue in teaching EFL classroom discourse due to its benefits and its loss in the application. Some believe that teaching English is better not to use the mother language whereas others believe that by using code-switching, it will affect the language acquisition of the students in mastery English. Enama (2016) states that the target language should be accompanied by $\mathrm{L} 1$ as in one framework so there is no burden of employing mother language because it serves the precise function in classroom to students. Therefore, the use of mother language in EFL classroom gives students more comfortable setting in which they are able to speak freely with no strict rule of English-only policy. On the other hand, some say that code-switching in teaching and learning a language should be avoided, because it will interfere the language acquisition for the students. Moreover, the use of mother language in classroom is sign of laziness, sloppiness and any other weaknesses during teaching and learning process or lack of competency (Brown, 2006).

Amidst the debate of pros and cons of code switching, one should be aware of the reason behind it to know whether code switching is applicable or not depending on various kinds of aspects, such as students' mastery. Students tend to switch language because their language ability is not equal as one to another or to their teachers' mastery as they are not the native speaker (Ustunel, 2016). Therefore, students ought to find the ways of communicating with their peers in convenient possible way by using mother language. Meanwhile, in order to overcome the gap of 
communication, teacher also switch language (Heredia \& Brown, 2005). This means that using more than one language in learning another language is common and useful in order to achieve the learning results.

Furthermore, Indonesia is known for its rich and variety of cultures and traditions. Having thousands of islands inhabited by different kinds of ethnic groups and society which makes Indonesia indeed as a very rich of local customs and languages country. In addition, Indonesia can be said as bilingual or multilingual country because people can speak more than one language. Even though they can speak more than one language, Indonesian people use Bahasa Indonesia as the national language. English as a foreign language in Indonesia has been complemented through wide use in education settings, especially at the university level, since English is a primary need when the students graduate from university.

The teaching and learning process of English as foreign language cannot be separated from the utilization of code-switching, especially at campus setting. Both lecturer and students who are not from English department class mix Bahasa Indonesia and English to avoid communication breakdown. Therefore, the realization of code-switching in learning English needs to be uncovered in regards to the forms and functions.

\section{METHODS}

The design of this study was classroom discourse analysis study which aimed to explore the code-switching carried out by the lecturer and the learners in English class at non-English department of Dian Nuswantoro University. The study was taken place in four classes of English subject. Each class consisted of around 30 students. This study investigated the codeswitching performed by the lecturer as well as the students related to the context of teaching and learning in English class. The data was gathered through recording and notetaking the teaching and learning process. Furthermore, the analysis scrutinized the forms and the functions of code-switching based on Poplack in Jenda (2012, p.75) and Hoffman (1991). Since, this study investigated specific phenomenon in specific context, the findings of the study were not generalized as applicable to another different context.

\section{RESULTS AND DISCUSSION}

The findings concern on the empirical data that was found during the analysis of codeswitching. While discussion examines and correlate the findings to the previous studies.

It was found that there were various kinds of code-switching in the English teaching and learning process at non-English department of Dian Nuswantoro university which were realized as the medium of communication between the students with the lecturer. The three types of code-switching were carried out into several different ways by means of different utterances also. The frequency of code switching could be seen on the Table 1 which summarized four-time meetings of English class with different lecturers.

Table 1 Type of Code-Switching in the classroom

\begin{tabular}{lllll}
\hline & \multicolumn{3}{l}{ Forms of utterance } & Total \\
\cline { 1 - 3 } Code & Intra & Tag & Inter & \\
switching & CS & CS & CS & \\
Meeting 1 & 25 & 23 & 47 & 95 \\
Meeting 2 & 18 & 22 & 54 & 94 \\
Meeting 3 & 30 & 27 & 26 & 83 \\
Meeting 4 & 34 & 26 & 60 & 120 \\
Total & 107 & 98 & 187 & 392 \\
\hline
\end{tabular}

Based on Table 1, there were 392 occurrences of code-switching done both by the lecturer as well as the students in English business classroom. The high occurrence of code-switching was the inter sentential codeswitching with total occurrence 187 utterances in which this code-switching occurred between clauses or sentence boundaries, where each clause or sentence was in one language or another (Hoffman, 1991). Meanwhile, this type 
of code-switching was followed by intra sentential code-switching with 107 occurrences in four English business meetings. Lastly, the tag code-switching came after it with total occurrence 98 utterances. Furthermore, the English for business class indicated that the use of code-switching was utilized to teach non EFL students.

In addition, the use of code-switching was not just a code switch, yet it has various kinds of reasons/ functions why people use it. Based on the findings, there have been 10 reasons why people are using code-switching according to Hoffman (1991). The findings could be seen as follows:

Table 2. Reasons of Code-Switching in the classroom

\begin{tabular}{|c|c|c|c|}
\hline No. & Reasons & $\mathrm{f}$ & $\%$ \\
\hline 1. & $\begin{array}{l}\text { Talking about a particular } \\
\text { topic }\end{array}$ & 50 & 13 \\
\hline 2. & Quoting somebody else & 7 & 2 \\
\hline 3. & $\begin{array}{l}\text { Being emphatic about } \\
\text { something }\end{array}$ & 82 & 21 \\
\hline 4. & Interjection & 98 & 25 \\
\hline 5. & Repetition & 58 & 15 \\
\hline 6. & $\begin{array}{l}\text { Intention to clarify the } \\
\text { speech content }\end{array}$ & 11 & 3 \\
\hline 7. & Expressing group identity & 10 & 2 \\
\hline 8. & $\begin{array}{l}\text { To soften and straighten } \\
\text { request or command }\end{array}$ & 18 & 4 \\
\hline 9. & Real lexical need to & 42 & 11 \\
\hline 10 & Exclude other people & 16 & 4 \\
\hline & Total & 392 & 100 \\
\hline
\end{tabular}

Based on Table 2, it could be seen that 10 reasons of the code-switching occurrence have been used in the teaching and learning process of non EFL classroom. The mostly used reason was interjection with the total occurrence 98 times which then followed by being emphatic about something as the second mostly used reason with total occurrence 82 . Meanwhile the least reason behind the use of code-switching was because the speaker is quoting someone else.

\section{Types of Code-Switching}

Basically, the classification is based on the portion different code is used in a sentence which resulted in the three categories of codeswitching. Moreover, the realization of codeswitching in the teaching and learning process was carried out into different ways.

\section{Intra-sentential Code-Switching}

Intra-sentential code-switching is a type of code-switching in which the speaker only put a word or phrase from different language in the sentence. According to Jenda (2012: 76) this type of code switching is found when a word, a phrase, or a clause of a foreign language is used within the sentence in a base language (on going means of communication). Here were the findings related to the use of intra-sentential code-switching.

\section{Word}

The intra-sentential code-switching might happen when a word from different language is put into a sentence as a substitution. The use of the word holds up certain value and function as it is usually brought up consciously by the speaker. Here is the example.

Table 3. Intra-sentential Code-Switching Word $\begin{array}{ll}\text { Person } & \text { Utterance } \\ \text { Lecturer } & \text { Drawing. Do you want to do }\end{array}$ something with drawing? So, this is the wrong place for you if you like drawing. You can be an architect or visual designer. No? you just like drawing. But what is your future jobs that you want?

Students Drawer.

Lecturer Bukan drawer. It's different. Drawer is cupboard. Drawer is different. To be what, Nadela?

Students May be Belum.

Based on Table 3 related to intrasentential code-switching word, the lecturer put Bahasa Indonesia word on her utterances. The word "bukan" was used in the lecturer sentence "Bukan drawer. It's different". In this case, the 
lecturer tried to correct the student's answer, when she gave him a question about the future job the student wants to get related to drawing skill. Thus, the student answer with the word "drawer" which he intends to define the person who is skilled in the field of drawing. However, the answer is directly understood by the lecturer that the student tries to define artists which then she replied it with "Bukan drawer, it's different". Rather than using the word "not", the lecturer spontaneously uses "bukan" as it is taken from Bahasa Indonesia translation from the word "not". After that, the lecturer tries to explain more about the answer that has been delivered by the student in English. The word "bukan" indicated a strong judgement from the lecturer that the student's answer is incorrect. In this case, the lecturer has made an intra-sentential code-switching which only a word put on the sentence.

\section{Phrase}

Phrase or a group of words could be also the realization of the intra-sentential codeswitching. As intra-sentential code-switching only utilize some elements of a sentence from different language. In bilingual communication, the code-switching sometimes is in a form of only phrase which sometimes functions to express the concept that does not exist in the language being talked about. Here is the example from the findings.

Table 4. Intra-sentential Code-Switching Phrase

\begin{tabular}{ll}
\hline Person & Utterance \\
Lecturer & So, you have to be grateful because \\
& you are here today \\
Student & Yes \\
Lecturer & No, don't do that. Ok, do you \\
& understand what I mean? Five \\
& minutes, three question. Okay, as \\
& long as you can answer my \\
& questions. Well, you get B, as long \\
& as you can get, as long as you can \\
& answer my question okay? \\
& Kalo enggak ya up to you. \\
Student & What score, Mam?
\end{tabular}

Based on Table 4, the lecturer utilizes intra-sentential code-switching in which she only uses a phrase in her sentence. The phrase "Kalo enggak $y a$ " in the sentence "Kalo enggak ya up to you" indicated that the lecturer gives a reminder to the students about the instructions. In this case the lecturer uses conditional phrase as a reminder to the students using Bahasa Indonesia phrase "kelo engga $\boldsymbol{y a}$ " as it is supposed to be "if not". Formerly, the lecturer has already reminded the students about the instruction in English; however, she ends up her utterances by using Bahasa Indonesia phrase as a completion. This code-switching is phrase to emphasize that that is important reminder to be noted by all students without any exceptions although it could be also be expressed in English. By switching the language, the lecturer intentionally gives more impression to the students. Based on the table 4.4, the lecturer utilizes intra-sentential code-switching in which she only uses a phrase in her sentence. The phrase "Kalo enggak ya" in the sentence "Kalo enggak ya up to you" indicated that the lecturer gives a reminder to the students about the instructions. In this case the lecturer uses conditional phrase as a reminder to the students using Bahasa Indonesia phrase "kelo engga $\boldsymbol{y a}$ " as it is supposed to be "if not". Formerly, the lecturer has already reminded the students about the instruction in English; however, she ends up her utterances by using Bahasa Indonesia phrase as a completion. This code-switching is phrase to emphasize that that is important reminder to be noted by all students without any exceptions although it could be also be expressed in English. By switching the language, the lecturer intentionally gives more impression to the students.

\section{Clause}

The use of clause as code-switching is quite similar to the word or phrase insertion into a sentence. In intra-sentential code-switching, a speaker tends to switch the language by replacing a clause from a sentence in which it somehow holds up certain function based on the situation. Here is the example from the research findings. 
Table 5. Intra-sentential Code-Switching Clause

\begin{tabular}{|c|c|}
\hline Lecturer & No bukannya driver. Okay, next \\
\hline Student & $\begin{array}{l}\text { Deni Permadi! } \\
\text { (Coming) }\end{array}$ \\
\hline Lecturer & $\begin{array}{l}\text { Yeah, okay. Please semuanya diam } \\
\text { dan listen carefully ya. }\end{array}$ \\
\hline Student & (Smiling) \\
\hline Lecturer & How are you? \\
\hline Student & I am fine \\
\hline Lecturer & $\begin{array}{l}\text { Okay. So, do you like my } \\
\text { company? }\end{array}$ \\
\hline Student & Yes \\
\hline
\end{tabular}

Based on Table 5, the lecturer uses intrasentential code-switching in a sentence by inserting the clause "semuanya diam dan" in the sentence "Please semuanya diam dan listen carefully $y a$ ". Based on the structure of the sentence, the lecturer instructs the students to do something which is to be silent and listen carefully to the upcoming speeches. In this case, when it comes to English, it is supposed to be "please be silent and listen carefully". However, the lecturer replaced into Bahasa Indonesia phrase which still carries the same meaning in English. Furthermore, the intention why the lecturer substitutes the English phrase into Bahasa Indonesia phrase is that the lecturer tries to command the students in respective way, so that they agree to follow it.

\section{Tag Code-Switching}

Tag code-switching is commonly utilized by a bilingual speaker when they insert short expression or a tag from different language at the end of their utterances. Usually, tag codeswitching is used as a tag to emphasize something as it functions as a tag. As Indonesian people, the use of the word " $\boldsymbol{y a h}$ " at the end of a sentence is quite common in daily communication. The occurrence of tag codeswitching holds up the highest used in the teaching and learning process for non EFL students. Here is one of the examples.
Table 6. Tag Code-Switching Word

$\begin{array}{ll}\begin{array}{ll}\text { Person } \\ \text { Lecturer }\end{array} & \begin{array}{l}\text { Utterance } \\ \text { Student do you like my company? } \\ \text { Your company my passion, I like } \\ \text { analyst assistant. I like }\end{array} \\ \text { Lecturer } & \begin{array}{l}\text { Do you want to be assistant analyst } \\ \text { here, yah? }\end{array} \\ \text { Student } & \begin{array}{l}\text { Yes } \\ \text { Lecturer }\end{array} \\ & \begin{array}{l}\text { Hmm, I have a lot of team here. So, } \\ \text { I want put you on a team. Do you } \\ \text { think you're able to work in a team? }\end{array} \\ \text { Student } & \text { Yes }\end{array}$

Based on Table 6, there could be found how the lecturer utilizes a tag code-switching from Bahasa Indonesia to her English speaking. The tag code switching is attached at the end of the sentence as an emphasis. Furthermore, the Indonesian people commonly used "yah" at the end of the sentence as polite way to ask question to other people. The use of " $\boldsymbol{y} \boldsymbol{a h}$ " by the lecturer in the sentence "Do you want to be assistant analyst here, $\boldsymbol{y} \boldsymbol{a h}$ ?" indicates that the lecturer tries to respect the student as employee candidate in Indonesian way. Besides, this tag code-switching also gives the students courage to speak in English and make them comfortable in his speaking.

\section{Inter-sentential Code-Switching}

Inter-sentential code-switching refers to the use of complete sentence which differs from the language being spoken. This type of cedeswitching takes place within the same sentence or between speaker turns which sometimes indicates fluency in both languages such that a speaker is able to follow the rules of two languages. It might also entail that the interlocutor cannot follow the speech which force the speaker to switch the language in making a full sentence. Here is the example from the finding. 
Table 7. Inter-sentential Code-Switching

\begin{tabular}{ll}
\hline Person & Utterance \\
Lecturer & Navy programmer. Okay good. So, \\
& in the nest page you see an article \\
& there, please read three minutes. In \\
& three minutes, read ! and please let \\
& me know what you think about the \\
& article. \\
& Sejauh ini apakah sudah ada yang \\
& pusing karena saya ngomong \\
& Bahasa Inggris terus? \\
Students & Agak. \\
Lecturer & Agak sedikit mengerti atau banyak \\
& yang tidak mengerti. \\
& Okay, no problem. Because for the \\
& final test, it's not only listening, you \\
& will have speaking. Okay. \\
& I there is word that you don't \\
& know, just ask me! \\
& $\begin{array}{l}\text { Finished? Have you finished } \\
\text { reading } \\
\text { Not yet }\end{array}$ \\
\hline
\end{tabular}

Based on Table 7, the lecturer gives an instruction to read the passages which then followed by the question. The question is expressed in Bahasa Indonesia which is different from language being used in the classroom. The sentence "Sejauh ini apakah sudah ada yang pusing karena saya ngomong Bahasa Inggris terus?" indicates that the lecturer is using intersentential code-switching that is in a form of full sentence. In addition, the question being expressed is completely out of the topic which does not have any relation with the previous utterances. When this sentence is switch into English, it is supposed to "Have you been confused since I speak in English thoroughly so far?". In this case, the lecturer intentionally asks the students in Bahasa Indonesia considering that the topic being discussed is different. Furthermore, the lecturer uses complete sentence or intersentential code-switching to invite the students not to worry if they express their idea through Bahasa Indonesia.

\section{Functions of Code-Switching}

The use of code-switching does not occur without no reason as many people assumed that it is common phenomena for bilingual people. Code-switching is usually anticipated to be a sign of language knowledge insufficiency in bilingual speakers. However, according to Shin (2010) code-switching is usually utilized by bilingual speakers to accomplish specific communicative intentions in their conversations with others. People tend to use other language as it is for the purpose of communication which help them to communicate easier and faster. There are a number of reasons why people utilize code-switching in their communication as proposed by (Hoffman, 1991). The findings of the study have met all the categories why codeswitching occurred in the teaching and learning process for non-English students.

\section{Talking about a particular topic}

When a speaker utilizes code-switching, sometimes it indicates that the speaker wants to talk about different or particular topic. By using code-switching, it enables the speaker to feel free and more comfortable to express their emotions, excitements or even anger in different language. Through the use of code-switching, people consider it as appropriate way to talk about something in particular. Here is the example.

Table 8. Talking about a particular topic

\begin{tabular}{|c|c|}
\hline Person & Utterance \\
\hline Lecturer & Mam? \\
\hline Students & $\begin{array}{l}\text { Yes, please. Wait, I want to listen } \\
\text { to Safira. Can you listen to Safira's } \\
\text { answer? }\end{array}$ \\
\hline Lecturer & No \\
\hline Students & $\begin{array}{l}\text { Hello class, I ask several students } \\
\text { here to give their own answer to } \\
\text { give you example. Supaya jawaban- } \\
\text { jawaban ini bisa dijadikan contoh for } \\
\text { others. So, your friend can listen } \\
\text { your answer and it can be a kind of } \\
\text { overview for all of them. Jadi bisa } \\
\text { digunakan untuk mereka misalkan "oh } \\
\text { iya ya jawabanya kayak gitu", gitu } \\
\text { Safira. Yap, please! }\end{array}$ \\
\hline
\end{tabular}




Lecturer Where do you see yourself in five
years times?

Based on the Table 8 , the lecturer asks several students to be role models how to answer the question correctly based on appropriate interview. At first, the lecturer demands the students' attention and is followed by the reason why she needs them by switching the language "Supaya jawaban-jawaban ini bisa dijadikan contoh for others". In this case, the lecturer utilizes intra-sentential code-switching by inserting Bahasa Indonesia clause into the sentence. Based on the context, the lecturer tries to talk about particular topic which can make the students willingly follow listen to the lecturer. After that, the lecturer continues her utterances by switching the language extending the utterances before she switches the language. However, at the end of lecturer's utterances, she adds up some additional details on what she has mentioned previously by switching the language again in the sentence "Jadi bisa digunakan untuk mereka misalkan "oh iya ya jawabanya kayak gitu", gitu Safira". The context of code-switching usage indicates that the lecturer carries out codeswitching in order to talk about particular topic. It aims to make the interlocutor to be more eager to follow the speech.

\section{Quoting somebody else}

Quotation is repeating somebody else which usually is in a form of wise advice. Quoting somebody else is commonly delivered based on its origin forms and languages. People tend to quote a famous expression of some wellknown figures. Here is the example.

Table 9. Quoting somebody else

\begin{tabular}{|c|c|}
\hline Person & Utterance \\
\hline Students & I want change the world. \\
\hline Teacher & $\begin{array}{l}\text { Oh... you want to change the } \\
\text { world. Ok why? }\end{array}$ \\
\hline Students & Money is not everything. \\
\hline Teacher & Okay. Uang bukanlah segalanya. \\
\hline Students & No money, no cry. \\
\hline
\end{tabular}

Based on Table 9, the lecturer is interviewing one of the students about pretending to be employee candidate in front of the other students. On this part, the lecturer asks the student about the motivation why he wants to change the world which then replied by the student that he wants to change the world "Money is not everything". Hearing the student's answer, the lecturer agrees by saying "Okay" and repeats it by changing the language into Bahasa Indonesia "Uang bukanlah segalanya" considering that this utterance deserve to be quoted and well understood by the other students. Furthermore, the lecturer is carrying out inter-sentential code-switching by completely change the whole sentence into another language with the purpose to quote somebody else utterance.

\section{Being emphatic about something}

The use of code-switching could also happen when someone wants to put emphasis on the things that he/she is talking about. Usually, when someone who is talking using a language that is not his native tongue suddenly wants to be emphatic about something, he/she, either intentionally or unintentionally, will switch from his second language to his first language. Here is the example.

Table 10. Being emphatic about something

\begin{tabular}{ll}
\hline Person & Utterance \\
Lecturer & Hello? \\
Lectudent & Yes \\
& $\begin{array}{l}\text { When, I say "hello" you said } \\
\text { "hello" not yes, okay. Ini bukan } \\
\text { mata kuliah Bahasa Indonesia ya }\end{array}$ \\
Student & $\begin{array}{l}\text { (laughing) } \\
\text { Lecturer }\end{array}$ \\
& $\begin{array}{l}\text { Hmm, okay. What position do you } \\
\text { apply in this place? }\end{array}$ \\
Student & $\begin{array}{l}\text { I want to apply job for tool men } \\
\text { and computer company in your } \\
\text { company. }\end{array}$ \\
&
\end{tabular}

Based on the Table 10, the lecturer ties to greet the student as she opens the interview by saying "hello". However, it is replied by the student using Indonesian way by saying "yes" 
which then considered should be corrected by the lecturer. The lecturer than gives an explanation to the student about what he is supposed to reply when someone greets him. In addition, she also gives an emphasis on the utterance by saying "Ini bukan mata kuliah

Bahasa Indonesia ya" explaining that the learning subject is not Bahasa Indonesia. In this case, the lecturer switches the language into Bahasa Indonesia in order to give emphatic statement that the student is learning English not Bahasa Indonesia which also might functions as satire to the students to study hard and try to speak English.

\section{Interjection}

As communication happens between people, it's common phenomena when interjection occurred following their utterances. Interjection is an emphatic exclamation which could be used also as expressing emotion. It also become an indication that bilingual people are having a communication. This insertion may happen intentionally or unintentionally according to the speakers' daily language use. Here is the example

Table 11. Interjection

\begin{tabular}{ll}
\hline Person & Utterance \\
\hline Lecturer & $\begin{array}{l}\text { Okay, to be a photographer. What } \\
\text { is your reason, why do you want to } \\
\text { apply for photographer position? }\end{array}$ \\
Students & $\begin{array}{l}\text { It's my hobby, it's my love to } \\
\text { explain more about the }\end{array}$ \\
& photography and may be \\
& connecting my love hobby and my \\
& job is.... \\
Lecturer & Is it a good thing yah? \\
Students & Yes \\
Lecturer & So, do you think you will be \\
& successful? \\
Students & Maybe I, but I will try it
\end{tabular}

Based on Table 11, the lecturer is still asking a student related to the job interview practice. The student seems to be enthusiastic and confident to answer the lecturer's question in English although there are some mistakes regarding to the word choices. After several question about hobby, the lecturer makes sure that the student's opinion is appropriate by asking "Is it a good thing $\boldsymbol{y a h}$ ?". The question basically has already met the requirement of good English sentence; however, since the lecturer adds up the word "yah" in the end of it, it indicates that the lecturer uses Indonesian way and give emphatic exclamation mark on it. As the word " $\boldsymbol{y a h}$ " is commonly used in Indonesian daily communication as interjection which functions as exclamation mark at the end of the sentence. In this case, the lecturer is carrying out code-switching as interjection for her utterance.

\section{Repetition}

Repeating words or phrases is one of communication strategies which is commonly used by people who communicate to each other. When a bilingual speaker wants to speak about something which is easily understood by the listener, he/she usually use both languages in repetitive manners. Here is the example.

Table 12. Repetition

$\begin{array}{ll}\text { Person } & \text { Utterance } \\ \text { Lecturer } & \text { Is it possible for HRD officer to } \\ & \text { give possible solution related to the } \\ & \text { problem toward the boss? } \\ \text { Students } & \text { (Silent) } \\ \text { Lecturer } & \text { Boleh? HRD kepala personalia itu } \\ & \text { memberikan saran solusi kepada } \\ \text { btudents } & \text { Yes } \\ \text { Lecturer } & \text { Yes, that is actually the role yah. } \\ & \text { Iya sebetulnya memang itu } \\ & \text { perannya, HRD officer gives the } \\ & \text { possible solution related to the } \\ & \text { problem faced by the employee, } \\ & \text { yah. Okay, prepare your things, } \\ & \text { you are going to listen the } \\ & \text { conversation. }\end{array}$

Based on Table 12, the lecturer is discussing with the students related to the roles of HRD in a company. At the first, the lecturer gives the students question about the possibility of HRD doing certain job. However, the 
students keep silent indicating that they have no idea to answer the question. Knowing that there is no answer from anyone, the lecturer than switch the language into Bahasa Indonesia wondering that the students might not understand yet about the questions by asking "Boleh? HRD kepala personalia itu memberikan saran solusi kepada bos?". This utterance is based on the previous utterance which is being translated "Is it possible for HRD officer to give possible solution related to the problem toward the boss?". In this case, the lecturer utilizes the intersentential code-switching in which the lecturer switches her language completely to create a sentence. Furthermore, the code-switching used in this utterances functions as a repetition of previous sentence. The repetition itself is based on the absence of students' answer from the former question.

\section{Intention to clarify the speech content}

In bilingual talk, clarifying speech content is common phenomena in which code-switching sometimes play important role. When bilingual people are having communication, there will be many code-switching that are used to make the content of the speech runs smoothly and can be easily understood by the interlocutor. Here is the example

Table 13. Intention to clarify the speech content

$\begin{array}{ll}\text { Person } & \text { Utterance } \\ \text { Lecturer } & \text { So, this is my bit weird question, } \\ & \text { what is the meaning of your name? } \\ \text { Student } & \text { My name Kartiko? } \\ \text { Lecturer } & \text { Ehmm. What is the meaning of } \\ & \text { Kartiko } \\ \text { Student } & \text { Kartiko Johar } \\ \text { Lecturer } & \text { No, maksud saya artinya. Do you } \\ & \text { know the meaning? } \\ \text { Student } & \text { No. } \\ \text { Lecturer } & \text { Definition? What is the definition } \\ & \text { of your name? }\end{array}$

Based on Table 13, the lecturer is wondering about the meaning of the student's name. She asks about the student's name by saying "So, this is my bit weird question, what is the meaning of your name?". However, the student gets it wrong assuming that the lecturer is asking about the name not the meaning. At the second time, the lecturer asks about the meaning of the name which once again the student answer with his name. Knowing that the student is confused, the lecturer then switches the language into Bahasa Indonesia by asking "No, maksud saya artinya. Do you know the meaning?". In this case, the lecturer only switches the language once which then followed by English sentence. The word "maksud saya" indicates that the lecturer wants to clarify the previous utterance to the student, so that he does not get it wrong. Furthermore, the lecturer utilizes code-switching in order to clarify speech content.

\section{Expressing group identity}

When people use code-switching in their communication, it acts as a mean to express their identity to the other people. The way of communication between one group of people differs to another, for example when academic group has a discussion, it is obviously different compare to other group of people.

Table 14. Expressing group identity

$\begin{array}{ll}\text { Person } & \text { Utterance } \\ \text { Lecturer } & \begin{array}{l}\text { Okay, you have to go to me, right } \\ \text { away. You understand my question }\end{array} \\ & \text { yah? } \\ \text { Student } & \text { No } \\ \text { Lecturer } & \text { No, you don't understand my } \\ & \text { question? Pie to mas } \\ \text { Student } & \text { Yes }\end{array}$

Based on the Table 14, the lecturer just finishes explaining something to the student who come to do interview practice. In order to check the student's understanding, the lecturer then make it sure by asking "Okay, you have to go to me, right away. You understand my question yah?". However, the student replies it with opposite answer saying that he doesn't know anything. This answer makes the lecturer a bit surprised that makes her to recheck it to the student by repeating his answer in complete form "No, you don't understand my question?". In addition, she 
adds her utterance by switching the language into Javanese language "pie to mas". This phrase is commonly used by Javanese society to express surprise and unbelief. This expression is used by older people to younger people or teacher to pupils based on the language stratification or higher status people to lower status people. In this case, the lecturer utilizes the intra-sentential code-switching into Javanese language in order to express the group identity.

\section{To soften and straighten request or command}

In daily communication, request and command are sometimes considered offensive to some people. Furthermore, people sometimes make some strategies to avoid being offensive by utilizing code-switching. It will give another impression, because the interlocutor feel that he/she is being respected.

Table 15. To soften and straighten request or command

\begin{tabular}{ll}
\hline Person & Utterance \\
Lecturer & I need you to explain about your \\
& strength and weakness? \\
Student & I can work with but I can't. I apply \\
& for back and web developer and \\
& work with programing language \\
& PHP, HTML, and JAVA. And I \\
& want to apply for back and web \\
& developer. \\
Lecturer & Okay, so you missed my question. \\
& Di dengarkan dulu ya. My question \\
& is what is your strength and \\
& weakness? \\
Student & My strength is I can work in every \\
& time but I can't work with team \\
& work.
\end{tabular}

Based on the Table 15, the lecturer looks up the student's information related to his weakness and strength in pretending to have interview. The question given from the lecturer is not well received by the student which makes him to answer the question incorrectly. The student thinks that he is asked about the reason why he apply for the job at that company. Knowing the answer is wrong, the lecturer immediately replies "Okay, so you missed my question" which tells the student that he has missed the meaning of question given to him. In addition, the lecturer adds "Di dengarkan dulu $\boldsymbol{y} \boldsymbol{a}$ " as a request to listen comprehensively toward the question given by switching the language into Bahasa Indonesia. Based on Bahasa Indonesia usage, the use of " $y a$ " at the end of the request represent a polite request to someone else. It is also directly followed by repetition of the question "My question is what is your strength and weakness?". In this case, the lecturer utilizes code-switching as a command to the student to soften the request in order to make the student understand it fully. Furthermore, this code-switching and also the repetition made by the lecturer has already made the student to rephrase his answer correctly on the second time by saying "My strength is I can work in every time but I can't work with team work".

\section{Real lexical need to}

Code-switching is also could be used when the speaker really needs to use it. In bilingual communication, the existence of certain word sometimes cannot be replaced by other word which means the speaker has to switch to another language. Thus, real lexical need to be brought up in the communication to help interlocutor understand the content being talked about. Here is the example.

Table 16. Real lexical need to

Person Utterance

Lecturer Okay thank you Raka, then next!

Lecturer Where do you see yourself in five years times?

Student I will be a good, I will be a good employee and work hard and advance the company.

Lecturer Okay, that's good [əd'va:ns]. You need to say [əd'va:ns] not [əd've:ns] but [əd'va:ns] the company (advance the company). Memajukan, okay thank you. The next! Bambang? 
Based on the Table 16, the lecturer is discussing with the students in front of the class by providing some questions to be answered by the students randomly who raise their hand. In that condition, the lecturer asks the student about how he sees himself in five years later. This question is then replied by the student by saying "I will be a good, I will be a good employee and work hard and advance the company" indicating that the student has strong motivation to be a good employee for the company. Hearing the student's answer, the lecturer then appreciates the answer followed by the elaboration of how to pronounce the words appropriately by saying "Okay, that's good [ad'va:ns]. You need to say [ad'va:ns] not [ad've:ns] but [ad'va:ns] the company. Memajukan,". Related to the elaboration produced by the student, the lecturer also adds the meaning of the word mentioned earlier "memajukan" as the translation of the word "advance". Furthermore, it can be said that the lecturer utilizes intra-sentential code-switching in order to give additional information about the word / lexical unit to the student because the it needs to. The word "memajukan" must be used, since it cannot be replaced by using other language.

\section{Exclude other people}

When people are communicating in a certain group, sometimes some people in the group use communication strategy which somehow exclude those people whom they don't want to share it. Furthermore, code-switching is the appropriate way to exclude other people, so that they don't understand the topic being discussed and ignore it. Here is the example.

Table 17. Exclude other people

$\begin{array}{ll}\text { Person } & \text { Utterance } \\ \text { Lecturer } & \text { Okay, So, Okay, how many of } \\ & \text { you, please raise your hand, how } \\ & \text { many of you that already have a } \\ \text { plan in your head? Angkat tangan } \\ \text { coba. } \\ \text { One, two, three, four, five, six, } \\ \text { seven, eight only eight. } \\ \text { Opo sih. }\end{array}$

\begin{tabular}{ll}
\hline Lecturer & $\begin{array}{l}\text { How many of you that have a plan } \\
\text { for your future? Okay, ten ya, } \\
\text { okay. }\end{array}$ \\
Student & Nanti kita tinggal nyebutin. \\
\hline
\end{tabular}

Based on Table 17, the lecturer is inviting the students to get involved in the discussed lead by her by asking those who have already had a plan in the future. The question delivered by the lecturer is "Okay, how many of you, please raise your hand, how many of you that already have a plan in your head?". Based on the structure of the question, the lecturer also inserts a request for the students to raise their hands. However, there is a unique phenomenon where some students are joking each other to raise their hand and one of them say "Opo sih" with irritated feelings showing that he does not want to raise his hand. The lecturer seems does not really care about what happens that she, then, repeats the question for the students. In this case, the way the student talk to his friend by switching the language using Javanese "Opo sih" indicates that he does not want the lecturer get involve on his utterance. Thus, the reason why the student utilize code-switching is that they want to exclude the lecturer from their discussion.

The current study has examined two classes of English subject conducted by the university lecturers with total four meetings. It was found that both lecturers and students were carrying out code-switching during the teaching and learning process. Most importantly the lecturer as the students' learning input, the lecturers sometimes intentionally change the language into Bahasa Indonesia while they talk in front of the classroom. There various types of code-switching as they were used by the lecturers in the classroom, namely: intrasentential code-switching, tag code-switching, and inter-sentential code-switching. This is in line with study conducted by Musmuliadi et al. (2018) that three types of code-switching are commonly utilized within the process of teaching instruction of English. Among three types of code-switching, inter-sentential codeswitching was recently used both by the lecturer and students. This situation implies that the 
code-switching between English and Bahasa Indonesia mostly happened in a full sentence which totally in one language. Furthermore, Maiza (2015) also stated that classroom interaction between the teacher and students utilized by code-switching could improve the ability of speaking. Moreover, it also entails that fluency in both languages such that a speaker is able to follow the rules of the two languages, since inter-sentential code-switching takes place within the same sentence or between speaker. This condition illustrated that the lecturer understand well about the way to utilize codeswitching in a full sentence.

Furthermore, the intra-sentential codeswitching is also frequently used although it is lesser than the inter-sentential code-switching. The lecturer tends to substitute certain words or phrases using Bahasa Indonesia words although the sentence is supposed to be full in English. Employing the intra-sentential code-switching does not merely change the correct structure of a sentence, it only gives reference to the students about the way to understand the meaning of certain words in a speech. This type of codeswitching is the most difficult to be created as the speaker has to be able to understand the structure as well as the context. As mentioned by Poplack and Sankoff (1986), that intrasentential code-switching is possibly the most complex type among the three, as it can occur at clausal, sentential or even word level. In this type of code-switching, inserting appropriate words or phrases should be meticulously done in order to avoid confusion among the students.

However, the tag code-switching is the least used code-switching among the three types. The tag code-switching is usually carried out as a filler or marker in a speech which could be place anywhere in a sentence. This is in line with Poplack and Sankoff (1986) stated that tag switching involves the insertions of tag in one language into one sentence or utterance in another language. The typically used of tag code-switching in university classroom is at the end of a sentence which indicates an emphasis about the sentence itself. This is in accordance with the Indonesian people typicality that in emphasizing something about their utterances, they usually put a certain filler at the end of a sentence to give more emphasis and naturally ask listeners to follow the instructions.

With regard to the function of codeswitching, this current study has proved that there are ten functions of the occurrence of codeswitching as proposed by Hoffman (1991). The lecturers and students utilize code-switching in the classroom because of interjection by which the code-switching is in a form of fillers or sentence connectors. This condition is quite understandable since fillers usually cannot be separated from the native language which is usually used in daily communication. The fillers, such as yah and loh (at the of the sentence) and to or kan (emphasize something), have been daily used by Indonesian people which then categorized as tag code-switching when the context is English. Hence, interjection holds up the mostly reason why lecturers and students are using code-switching in the classroom.

The function behind the use of codeswitching in the classroom was also being emphatic about something. The lecturers mostly utilize the code-switching in order to give emphasis toward certain topic for the sake of students' better understanding about the materials. This reason was then followed by repetition as the third highest reason why codeswitching occurred in the classroom. The repetition is usually carried out when the first statement seems do not manage to make all the students get the points, the lecturers eventually repeat the sentence in Bahasa Indonesia either as the translation from the sentence or the main idea of the sentence they mentioned earlier in English. This is in line with Muin (2011) that code-switching is commonly carried out in the interaction in learning new language since it has functioned as communication strategy in expressing ideas. Furthermore, this repetition acts as a mean of clarification as mentioned by Hoffman (1991) that when a bilingual wants to clarify his/her speech so that it will be understood more by the listener, he/she can sometimes use both of the languages that he masters saying the same utterance. This is also 
confirmed by Astani et al. (2020) that repetition tends to be frequently used as Indonesian speaker in utilizing code-switching. The other mostly used functions behind the occurrence of the code-switching are talking about particular topic which then followed by real lexical need to. When the lecturers talked about certain topic which out of the ongoing discussion context, they utilize code-switching in order to bring the students toward another topic. This is in line with Holmes (2013, p.38) who states that it is easier for some people to discuss a particular topic by switching to another code. Hence, codeswitching is the appropriate mean to bring the audience toward different topics. Furthermore, the code-switching in this case is used as a mean to talk about certain topic. Then and Ting (2011) stated that the changing of language could help emphasize the message and clarify the speech content to the audience in terms of pedagogical function of code-switching. Modupeola (2013) also mentioned that code-switching has become a teaching strategy for language instructor to improve students' learning outcomes. Meanwhile, the code-switching become a necessary thing when English could not define it precisely because of cultural gap among two different languages. In this case, the codeswitching must be employed to fill this gap in order to avoid communication breakdown. This is in line with the study conducted by Caparas and Gustilo (2017) and Balukas (2014) that the use of code-switching also could help in accommodating the speech, constructing the identity and exhibiting power.

Moreover, the lecturers carried out the code-switching as it also functions to soften and straighten request or command to the students. Without a deep knowledge about the language use especially English, sometimes the request and command could be regarded as impolite expression due to different culture. Considering this case, the lecturers choose to switch the language to give positive acceptance for the students without opposing them. Hence, the request or command is followed by codeswitching as cultural linguistic features which familiar to the students. Meanwhile, the function of code-switching to exclude other people was also possible since there were Javanese language apart from Bahasa Indonesia for switching the language. This function is usually addressed to those who do not want others to join the discussion as the students are talking each other in Javanese language, because they don't want the lecturer to get involve to the conversation considering that the lecturer won't understand the topic they are discussing with. This is quite similar to the function of expressing group identity when the lecturer use code-switching to prove that she is the lecturer. The students also consider to use code-switching in which it expresses the identity of the students. Likewise, the students sometimes use Javanese language to talk with their peer which represents their identity as Javanese people.

The last and least used function of codeswitching is quoting somebody else which talks about the statement that has been spoken by other people in the past which regarded as famous expression, proverb, or saying of some well-known person and valuable to be told as appropriately suited with the context of university students. Code-switching becomes a mean to deliver the quotation since the quotation required to be original which is taken from the original language. As the subject is English for non-English department class, the quotation was taken from anybody from which the expressions are appropriate to be quoted. Quoting somebody else is commonly delivered in the original version of the quotation. If the quotation is transformed into other language, it would give different impact toward listeners. Overall, the code-switching in English classroom has facilitated the learning process of English subjects for university students. This is in line with Zainil (2019) mentioned that codeswitching has aided the lecturers to manage the English classroom interaction as it gives pedagogical implication, such as to teaching grammar, explaining new vocabulary (translation), helping students to focus, maintaining the flow of the lesson, checking comprehension, confirmation check, and concept checking. In addition, Haryanti et al 
(2018) also confirmed that employing condeswitching in teaching English had positive influences toward the students' English skills. This is also confirmed by Noli et al. (2012) and Puspawati (2018) that students tended to exhibit positive attitudes toward code-switching because it helps them to understand the materials. Besides, Mukti \& Muljani (2016) also stated that the use of code-switching done by language instructor is mainly for the students' understanding. However, Yuanita et al. (2019) suggested that code-switching should be reduced by the language instructor because the students are learning the subject content not the linguistic content.

\section{CONCLUSION}

The result of the current study showed that code-switching in the classroom could be made in a form of using full sentence of different language, inserting certain words/phrases and inserting fillers. The code-switching utilized in classroom condition also showed various kinds of functions which could give benefit to the teaching and learning process and was positively perceived by the students.

It is suggested that code-switching is supposed to be used to in teaching and learning context, especially English class in university environment for non-English department in order to facilitate the students' learning process. It is also advised that a lecturer has to be able to utilize code-switching appropriately considering what types should be used and what function should be chosen.

\section{REFERENCES}

Astani, W., Rukmini, D., \& Sutopo, D. (2020). The impact of code switching in conversation of "nebeng boy" youtube vlogs towards communication in English among the participants. English Education Journal, 10(2), 182-189.

Balukas, C. (2014). Spanish-English bilingual voice onset time in spontaneous code- switching. International Journal of Bilingualism, 19(4), 423-443.

Brown, K. (Ed.). (2006). Encyclopedia of language and linguistics. Elsevier.

Caparas, P., \& Gustilo, L. (2017). Communicative aspects of multilingual code switching in computer-mediated Communication. Indonesian Journal of Applied Linguistics, 7(2), 349-359.

Enama, P. R. B. (2016). The impact of Englishonly and bilingual approaches to EFL instruction on low-achieving bilinguals in Cameroon: An empirical study. Journal of Language Teaching and Research, 7(1), 1930.

Haryanti, A., Mujiyanto, J., \& Faridi, A. (2018). The influence of teachers' code switching on students' understanding on their messages. English Education Journal, 8(4), 461-468).

Heredia, R., \& Brown, J. M. (2005). Codeswitching: The encyclopaedia of linguistics. Taylor \& Francis.

Hoffmann, C. (1991). An introduction to bilingualism. Longman Group.

Holmes, J. (2017). An introduction to sociolinguistics. Routledge.

Jenda, M. (2012). Sociolinguistics, the study of societies' language. Graha Ilmu

Krashen, S. D., \& Terrell, T. D. (1983). The natural approach Language acquisition in the classroom. Pergamon Press.

Maiza, M., Rukmini, D., \& Sofwan, A. (2015). Teachers' basic questionings used by English teachers in teaching English. English Education Journal, 5(1).

Margana, M. (2013). Alih kode dalam proses pembelajaran bahasa inggris di SMA. LITERA, 12(1).

Modupeola, O. R. (2013). Code-Switching as a teaching strategy: Implication for English language teaching and learning in a multilingual society. IOSR Journal of Humanities and Social Science, 14(3), 92-94.

Muin, A. (2011). Code-switching as a communication strategy. Jurnal Adabiyah, 11(2). 
Mukti, T. W., \& Muljani, R. (2016). Code switching in the instructions of English language education study program lecturers. LLT Journal: A Journal on Language and Language Teaching, 19(1).

Musmuliadi., Mujiyanto, J., \& Sutopo, D. (2018). The realization of teachers' code switching in instructional process. English Education Journal, 8(4), 432-438.

Noli, M. N., Farrah, D. R A., Sharifah, I. S. S. Z., \& Roslan, S. (2012). ESL learners' reactions towards code switching in classroom settings. Procedia - Social and Behavioral Sciences. 90, 478 - 487.

Payne, M. (2011). Exploring Stephen Krashen's ' $i+1$ ' acquisition model in the classroom. Linguistics and Education, 22(4), 419-429.

Poplack, S., \& Sankoff, G. (1986). The social life of language. Language, 62(1), 189.
Puspawati, I. (2018). Teachers' use of code switching in EFL classroom and its functions. Journal of Foreign Language Teaching and Learning, 3(1).

Then, D. C.O., \& Ting, S. H. (2011). Codeswitching in English and science classrooms: More than translation. International Journal of Multilingualism. 8(4), 299-323.

Üstunel, E. (2016). EFL classroom code-switching. Palgrave Macmillan.

Yuanita, W. E., Ratmadina., \& Syafei, F. (2019). An analysis of English teachers' code switching and code mixing in classroom instructions at SMA Pembangunan Laboratorium UNP. Journal of English Language Teaching, 8(3).

Zainil, Y. (2019). Pedagogical practices of codeswitching in EFL classrooms in Padang, Indonesia. KnE Social Sciences, 3(14), 634. 